\title{
Influence of Er,Cr:YSGG Laser on Bond Strength of Self-Adhesive Resin Cement
}

\author{
Matheus Coelho Bandéca ${ }^{a *}$, Shelon Cristina Souza Pinto ${ }^{\mathrm{b}}$, Luiz Rafael Calixto ${ }^{\mathrm{b}}$

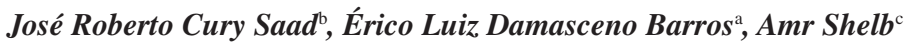 \\ a Department of Dentistry, Centre Universitary of Maranhão - UNICEUMA, \\ Rua Josué Montello, 1, Renascença II, CEP 65075-120, São Luís, MA, Brazil \\ ${ }^{\mathrm{b}}$ Department of Restorative Dentistry, Araraquara Dental School, \\ Universidade Estadual Paulista - UNESP, Rua Humaitá, 1680, \\ CEP 14801-903, Araraquara, SP, Brazil \\ ${ }^{\mathrm{c}}$ Department of Restorative Dentistry, Faculty of Dentistry, \\ Suez Canal University, el-Shikg Zayed, 41522, Ismailia, Egypt
}

Received: August 6, 2011; Revised: February 26, 2012

\begin{abstract}
The purpose of this study was to investigate the bond strength of fiber post previously laser treated root canals. Forty single-rooted bovine teeth were endodontically treated, randomly and equally divided into two main groups according to the type of pretreatment: $\mathrm{G} 1: 2.5 \% \mathrm{NaOCl}$ (control group); and G2: Er,Cr:YSGG laser. Each group was further subdivided into 2 groups based on the category of adhesive systems/luting materials used: a: an etch-and-rinse resin cement (Single Bond/RelyX ARC; 3M ESPE), and b: a self-adhesive resin cement (Rely X Unicem; 3M ESPE). Three $1.5 \mathrm{~mm}$ thick slabs were obtained per root and the push-out test was performed at a crosshead speed of $0.5 \mathrm{~mm} / \mathrm{min}$ until post dislodgement occurred. Data were analyzed by ANOVA and post-hoc Tukey's test at a pre-set alpha of 0.05 . Analysis of variance showed no statistically significant difference $(p>0.05)$ among the groups G1a (25.44 \pm 2.35$)$ and G1b (23.62 \pm 3.48$)$, G2a (11.77 \pm 2.67$)$ and G2b (9.93 \pm 3.37$)$. Fractures were observed at the interface between the dentin and the resin in all groups. The Er,Cr:YSGG laser irradiation did not influence on the bond strength of the resin cements and the etch-and-rinse resin cement had better results on bond strength than self-adhesive resin cement.
\end{abstract}

Keywords: Er,Cr:YSGG laser, root canal dentin, push-out bond strength, fiber post, resin cement

\section{Introduction}

Successful endodontic treatment consists on cleaning, shaping, disinfecting and sealing the root canal. Cleaning occurs simultaneously with biomechanical preparation, elimination of bacteria, their sub-products, degenerated pulp tissue and contaminated dentin creating a surgical space that permits proper sealing ${ }^{1}$.

However, conventional root canal preparation and rinsing solutions cannot always eliminate the remaining bacteria in the root canal ${ }^{2}$. A complementary method for the disinfection of root canals is the use of high-intensity lasers.

The Er,Cr:YSGG laser is generally used for removing organic and inorganic tissues along the root canal and reducing bacterial contamination significantly ${ }^{3}$. It provides a wavelength that coincides with the maximum absorption wavelength of water and hydroxyapatite and the surrounding tissues are minimally affected ${ }^{3}$.

The use of laser for reducing bacterial contamination along the root canal modifies the dentine surface of the root $\mathrm{canal}^{3}$. The dentin surface is an important aspect for cementation of intraradicular posts.

Self-adhesive luting materials were introduced recently to reduce the number of cementation steps by eliminating the pre-treatment of the tooth ${ }^{4-7}$. Their adhesion originates

*e-mail: matheus.bandeca@utoronto.ca by acidic monomers that simultaneously demineralize and infiltrate the tooth substrate, resulting in micromechanical retention $^{8-11}$. In additional, secondary reactions provide additional chemical bonding to the dentin surface ${ }^{6,3}$.

The modification of dentin surface influence directly the bond strength of the luting cements in the root canal and there is no study about the influence of high-intensity lasers on bond strength of self-adhesive luting materials. The purpose of this study was to verify the retention of fiber post luted with self-adhesive resin cement.

\section{Material and Methods}

\subsection{Specimen preparation}

The crowns of bovine teeth were removed at the cement-enamel junction using a low-speed diamond disc (Isomet III; Buehler, Lake Bluff, IL) under constant water-cooling.

The root canals were prepared until $1 \mathrm{~mm}$ from the apex using rotary nickel titanium instruments (Mity, Loser, Leverkusen, Germany) according to the crown-down technique. The master apical file was 40.06 and the irrigation solution between instrumentation was $2.5 \% \mathrm{NaOCl}$. Prepared root segments were obturated with gutta-percha 
and an epoxy resin-based canal sealer (AH Plus ${ }^{\circledR}$, Dentsply DeTrey, Konstanz). The specimens were then stored at $37^{\circ} \mathrm{C}$ and $100 \%$ relative humidity for a period of 24 hours.

\subsection{Post preparation}

The post space of each specimen was enlarged with a $n^{\circ} .2$ drill from the Exacto post system (Angelus, PR, Brazil) to a length of $10 \mathrm{~mm}$, leaving $4 \mathrm{~mm}$ of gutta-percha remaining in the apical third. To standardize the method, the same operator performed all the procedures.

\subsection{Pre-treatment of root canal walls}

Forty single-rooted bovine teeth were randomly and equally divided into two main groups according to the type of pretreatment:

G1: $2.5 \% \mathrm{NaOCl}$ (control group) - The irrigation occurred during 60 seconds;

G2: Er,Cr:YSGG laser - The laser equipment used was a Waterlase Millenium system (Biolase Technologies, San Clemente, CA), which emits photons at a wavelength of $2,78 \mu \mathrm{m}$. The output power was $0.75 \mathrm{~W}$ and water/air flow of 24 and $34 \%$, respectively. The focal area of the tip was $320 \mu \mathrm{m}$.

\subsection{Post cementation}

Each group was further subdivided into 2 groups based on the category of adhesive systems/luting materials used:

A: Etch-and-rinse resin cement (Single Bond/RelyX ARC; 3M ESPE, St Louis, USA) - Intracanal dentin was etched with $37 \%$ phosphoric acid for 15 seconds, rinsed with distilled water for 15 seconds, and then gently dried with absorbent paper points. After etching the dentin, the cement was inserted into the root canal and the fiber post was inserted and excess cement was removed;

B: Self-adhesive resin cement (Rely X Unicem; 3M ESPE3M ESPE, St Louis, USA) - The cement was inserted into the root canal and the fiber post was inserted and excess cement was removed.

All specimens were light activation for 30 seconds at the buccal and lingual surfaces, for a total of 60 seconds of light exposure, with $5 \mathrm{~mm}$ of distance between source and root.

\subsection{Push-out bond testing}

Three $1.5 \mathrm{~mm}$ thick slabs from cervical root region were obtained per specimen and were positioned on a base, with a central hole, in a universal testing machine (DL2000, EMIC, São José dos Pinhais, PR, Brazil). The push-out test was performed by applying a compressive load by using a cylindrical plunger attached to the upper portion of the testing machine. A crosshead speed of $0.5 \mathrm{~mm} / \mathrm{min}$ was applied until post dislodgement occurred.

The peak force, at the point of post segment extrusion from the test specimen, was used as the point of bond failure and recorded in Newton (N). Then, push-out bond strength values in MPa were calculated dividing this force by the bonded area of the post segment. This refers to the lateral surface of a post, which is calculated using the following equation:

$\mathrm{S}=2 \varpi \mathrm{r} \times \mathrm{h}$

where $\varpi$ is the constant $3.14, \mathrm{r}$ is the post radius and $\mathrm{h}$ is the slice thickness in $\mathrm{mm}$.

\subsection{Statistical analysis}

The data obtained was submitted to normality test (Shapiro Wilk). Normal data was found; therefore two-way ANOVA test was used to compare variables (pre-treatment and adhesive systems/luting materials). Post-hoc tests were conducted using a Tukey's multiple comparison test at $\mathrm{p}<0.05$.

\section{Results}

The results of the bond strength analysis were submitted to normality test in order to verify their normal distribution (Table 1). Considering that the obtained data were parametric, the analysis were performed by using the 2-way analysis of variance (ANOVA) (Table 2) and a post hoc test using the Tukey multiple comparison test at $\alpha=0.05$ (Table 3). The mean (MPa) and standard deviation for all groups are in Table 4. All failures occurred at the dentin/resin interface.

Table 1. Normality test applied for all groups.

\begin{tabular}{cccc}
\hline Groups & W & p value & Alpha $=\mathbf{0 . 0 5}$ \\
\hline G1a & 0.9596 & 0.3027 & ns \\
G1b & 0.9565 & 0.2516 & ns \\
G2b & 0.9424 & 0.1057 & ns \\
G2b & 0.9542 & 0.2182 & ns \\
\hline
\end{tabular}

$\mathrm{ns}=$ No difference significant.

Table 2. ANOVA 2-way analysis of variance.

\begin{tabular}{lcrc}
\hline & SS & df & MS \\
\hline Treatment (between columns) & 5709 & 3 & 1903 \\
Treatment (between rows) & 326.1 & 29 & 11.25 \\
Residual (random) & 725.0 & 87 & 8.334 \\
Total & 6760 & 119 & \\
\hline
\end{tabular}

Table 3. Tukey multiple comparison test at $\alpha=0.05$.

\begin{tabular}{ccccr}
\hline & $\begin{array}{c}\text { Mean } \\
\text { diff. }\end{array}$ & q & Summary & \multicolumn{1}{c}{$\begin{array}{c}\text { 95\% Cl } \\
\text { of diff. }\end{array}$} \\
\hline $\mathrm{G} 1 \mathrm{a} \times \mathrm{G} 1 \mathrm{~b}$ & 13.67 & 25.94 & $* * *$ & 11.71 to 15.63 \\
$\mathrm{G} 1 \mathrm{a} \times \mathrm{G} 2 \mathrm{a}$ & 1.820 & 3.453 & $\mathrm{~ns}$ & -0.1373 to 3.777 \\
$\mathrm{G} 1 \mathrm{a} \times \mathrm{G} 2 \mathrm{~b}$ & 15.50 & 29.40 & $* * *$ & 13.54 to 17.45 \\
$\mathrm{G} 1 \mathrm{~b} \times \mathrm{G} 2 \mathrm{a}$ & -11.85 & 22.48 & $* * *$ & -13.81 to 9.893 \\
$\mathrm{G} 1 \mathrm{~b} \times \mathrm{G} 2 \mathrm{~b}$ & 1.827 & 3.467 & $\mathrm{~ns}$ & -0.1300 to 3.785 \\
$\mathrm{G} 2 \mathrm{a} \times \mathrm{G} 2 \mathrm{~b}$ & 13.68 & 25.95 & $* * *$ & 11.72 to 15.63 \\
\hline
\end{tabular}

***Difference significant; ns = no difference significant.

Table 4. The push-out bond strength of all groups.

\begin{tabular}{ccc}
\hline & Mean & SD \\
\hline G1a & $25.44^{\mathrm{a}}$ & 2.35 \\
G1b & $11.77^{\mathrm{b}}$ & 2.67 \\
G2a & $23.62^{\mathrm{b}}$ & 3.48 \\
G2b & $9.93^{\mathrm{a}}$ & 3.37 \\
\hline
\end{tabular}

*Means followed by the same letters do not differ significantly $(\alpha=0.05)$. 


\section{Discussion}

The Er,Cr:YSGG laser has been used widely in endodontic therapy due to their microbial reduction potential $^{12-16,3,17}$. This laser has capacity of ablate enamel and dentin by the high absorption in water and also strong absorption by the hydroxyl radicals present in the hydroxyapatite structure ${ }^{12,18}$. Furthermore, it can create precise hard tissue cuts through the interaction of laser energy with atomized water droplets on the tissue interface resulting in the ablation of the tissue $e^{19,16,17}$.

Most of smear layer and debris on root canal walls is removed by Er,Cr:YSGG laser, and dentinal tubules were patent ${ }^{18,13}$. The smear layer is composed of cut tooth structure and some nonspecific inorganic contaminants ${ }^{13,11}$. Different irrigant solutions have been used in order to remove smear layer partially, such as $\mathrm{NaOCl}$ and $\mathrm{EDTA}^{20-22}$. The $\mathrm{NaOCl}$ is an irrigant solution used widely in root canal treatment due to its bactericidal properties and ability to dissolve organic tissues ${ }^{20,21}$.

Görgüi et al..$^{23}$ investigated the adaptation of a packable composite resin to lased root canal dentine when it was used as post material. The authors have found poor adaptation to root canal dentin when laser was applied at canal wall and more microleakage was detected. The alteration of dentine surface morphology at the root canal is an important aspect that influences the quality of adhesion between the filling material and root canal wall. Resin cements can be classified according to their mechanism of interaction with the smear layer. These cements can require application of an etch-and-rinse adhesive system or a self-etching primer. More recently, new resin cement was introduced which does not require any pre-treatment of dentin surface. Their clinical success is based on their ability to adequately bond to different restorative substrates and on their reduced technique and operator sensitivity ${ }^{24,25}$. For resin cement that requires an etch-and-rinse adhesive system (i.e. Relyx ARC), the application of $37 \%$ phosphoric acid promotes the removal of the smear layer and its adhesion is caused by the resin tags formation in depth. It explains our results, which showed that RelyX ARC did not affect by the laser application.

According to literature ${ }^{26-28}$, the self-adhesive resin cement showed lower values of bond strength than etch-and-rinse adhesives used to resin cement. The self-adhesive resin cement is based on methacrylated phosphoric acid esters with several cement reactions during setting ${ }^{29,30,9}$. The acidic groups bind with calcium in the hydroxyapatite to form a stabilizing attachment between the methacrylate network and the tooth ${ }^{4,5}$. However, there is very limited interaction with enamel or dentin in terms of either smear layer demineralization or tag formation. Despite the partial removal of the smear layer, our results show that this cement had no significant difference after laser application.

Other studies ${ }^{31,32}$ showed that the resin cements do not differ on bond strength values with pre-treatment of laser irradiations. However, Ramos et al. ${ }^{33}$ showed the weakest adhesion for laser-ablated dentin surfaces when used Er:YAG laser irradiation $(0.16 \mathrm{~W} 2 \mathrm{~Hz} / 80 \mathrm{~mJ})$. The authors explained that laser irradiation severely undermined the formation of consistent resin-dentin hybridization zones and yielded lower bond strengths. Capa et al. ${ }^{32}$ reported that the effect of laser application depends on type of laser, energies density and tooth hard tissue (enamel and dentin).

\section{Conclusion}

The Er,Cr:YSGG laser irradiation did not influence on the bond strength of the resin cements and the etch-and-rinse resin cement had better results on bond strength than self-adhesive resin cement. The self-adhesive resin cement without pre-treatment of dentin promotes a very limited interaction in terms of either smear layer demineralization or tag formation, reducing the bond strength.

\section{References}

1. Marchesan MA, Arruda MP, Silva-Sousa YT, Saquy PC, Pecora JD and Sousa-Neto MD. Morphometrical analysis of cleaning capacity using nickel-titanium rotary instrumentation associated with irrigating solutions in mesio-distal flattened root canals. Journal of Applied Oral Science. 2003; 11(1):55-59. http://dx.doi.org/S1678-77572003000100010

2. Beer F, Buchmair A, Wernisch J, Georgopoulos A and Moritz A. Comparison of two diode lasers on bactericidity in root canals-an in vitro study. Lasers in Medical Science. 2011;27(2):361-364. http://dx.doi.org/10.1007/s10103-011-0884-3

3. Silva AC, Guglielmi C, Meneguzzo DT, Aranha AC, Bombana AC and De Paula Eduardo C. Analysis of permeability and morphology of root canal dentin after Er,Cr:YSGG laser irradiation. Photomedicine \& Laser Surgery. 2010; 28(1):103-108. PMid:19764896. http://dx.doi. org/10.1089/pho.2008.2417

4. Naumann M,Sterzenbach G, RosentrittM,BeuerF, Meyer-Luckel $\mathrm{H}$ and Frankenberger R. Self-adhesive cements as core buildups for one-stage post-endodontic restorations? International Endodontic Journal. 2011; 44(3):195-202. PMid:21039623. http://dx.doi.org/10.1111/j.1365-2591.2010.01797.x
5. Oliveira AS, Ramalho ES, Ogliari FA and Moraes RR. Bonding self-adhesive resin cements to glass fibre posts: to silanate or not silanate? International Endodontic Journal. 2011; 44(8):759-63. PMid:21470250. http://dx.doi. org/10.1111/j.1365-2591.2011.01883.x

6. Pisani-Proenca J, Erhardt MC, Amaral R, Valandro LF, Bottino MA and Del Castillo-Salmeron R. Influence of different surface conditioning protocols on microtensile bond strength of self-adhesive resin cements to dentin. Journal of Prosthetic Dentistry. 2011; 105(4):227-235. http://dx.doi.org/ S0022-3913(11)60037-1

7. Zaitter S, Sousa-Neto MD, Roperto RC, Silva-Sousa YT and El-Mowafy O. Microtensile bond strength of glass fiber posts cemented with self-adhesive and self-etching resin cements. The Journal of Adhesive Dentistry. 2011; 13(1):55-59. http:// dx.doi.org/10.3290/j.jad.a1839618396

8. Kitzmuller K, GrafA, Watts D and Schedle A. Setting kinetics and shrinkage of self-adhesive resin cements depend on cure-mode and temperature. Dental Materials. 2011; 27(6):544-551. http:// dx.doi.org/S0109-5641(11)00025-X 
9. Liu Q, Meng X, Yoshida K and Luo X. Bond degradation behavior of self-adhesive cement and conventional resin cements bonded to silanized ceramic. Journal of Prosthetic Dentistry. 2011; 105(3):177-184. http://dx.doi.org/S00223913(11)60026-7

10. Muraguchi K, Minami H, Minesaki Y, Suzuki S and Tanaka T. A study of self-adhesive resin cements for bonding to silver-palladium-copper-gold alloy - Effect of including primer components in cement base. Dental Materials Journal. 2011; 30(2):199-205. http://dx.doi.org/JST.JSTAGE/ $\mathrm{dmj} / 2010-093$

11. Schenke F, Federlin M, Hiller KA, Moder D and Schmalz G. Controlled, prospective, randomized, clinical evaluation of partial ceramic crowns inserted with RelyX Unicem with or without selective enamel etching. Results after 2 years. Clinical Oral Investigations. 2011. http://dx.doi.org/10.1007/ s00784-011-0516-0

12. Chen WH. Laser root canal therapy. Journal of Indiana Dental Association. 2002; 81(4):20-3. PMid:12593182.

13. Ishizaki NT, Matsumoto K, Kimura Y, Wang X, Kinoshita J, Okano SM et al. Thermographical and morphological studies of Er,Cr:YSGG laser irradiation on root canal walls. Photomedicine and Laser Surgery. 2004; 22(4):291-297. PMid:15345170. http://dx.doi.org/10.1089/1549541041797814

14. Minas NH, Meister J, Franzen R, Gutknecht N and Lampert F. In vitro investigation of intra-canal dentine-laser beam interaction aspects: I. Evaluation of ablation capability (ablation rate and efficiency). Lasers in Medical Science. 2010; 25(6):835-840. PMid:19636663. http://dx.doi.org/10.1007/s10103-009-0701-4

15. Schoop U, Barylyak A, Goharkhay K, Beer F, Wernisch J, Georgopoulos A et al. The impact of an erbium, chromium:yttrium-scandium-gallium-garnet laser with radial-firing tips on endodontic treatment. Lasers in Medical Science. 2010; 24(1):59-65. PMid:18027065. http://dx.doi. org/10.1007/s10103-007-0520-4

16. Schoop U, Goharkhay K, Klimscha J, Zagler M, Wernisch J, Georgopoulos A et al. The use of the erbium, chromium:yttrium-scandium-gallium-garnet laser in endodontic treatment: the results of an in vitro study. Journal of American Dental Association. 2010; 138(7):949-955. http:// dx.doi.org/138/7/949

17. Soares F, Varella CH, Pileggi R, Adewumi A and Guelmann M. Impact of Er,Cr:YSGG laser therapy on the cleanliness of the root canal walls of primary teeth. Journal of Endodontics. 2008; 34(4):474-477. http://dx.doi.org/10.1016/j. joen.2008.02.006

18. Hadley J, Young DA, Eversole LR and Gornbein JA. A laser-powered hydrokinetic system for caries removal and cavity preparation. Journal of American Dental Association. 2000; 131(6):777-785. PMid:10860330.

19. Olivi G, Genovese MD, Maturo P and Docimo R. Pulp capping: advantages of using laser technology. European Journal of Paediatric Dentistry. 2007; 8(2):89-95. PMid:17571933.

20. Siqueira Junior JF, Rocas IN, Favieri A and Lima KC. Chemomechanical reduction of the bacterial population in the root canal after instrumentation and irrigation with $1 \%, 2.5 \%$, and $5.25 \%$ sodium hypochlorite. Journal of Endodontics. 2000; 26(6):331-334. http://dx.doi. org/10.1097/00004770-200006000-00006

21. Siqueira Junior JF, Rocas IN, Santos SR, Lima KC, Magalhaes FA and De Uzeda M. Efficacy of instrumentation techniques and irrigation regimens in reducing the bacterial population within root canals. Journal of Endodontics. 2002; 28(3):181-184. http://dx.doi.org/10.1097/00004770-200203000-00009

22. Sen BH, Wesselink PR and Turkun M. The smear layer: a phenomenon in root canal therapy. International Endodontic Journal. 1995; 28(3):141-148. http://dx.doi. org/10.1111/j.1365-2591.1995.tb00289.x

23. Görgül G, Kivanç BH, Maden M, Ulusoy OI and Tinaz AC. Effects of Nd: YAG laser irradiation on the adaptation of composite resins to root dentin. Journal of Contemporary Dental Practice. 2005; 6(4):116-23. PMid:16299613.

24. Ferracane JL, Stansbury JW and Burke FJ. Self-adhesive resin cements - chemistry, properties and clinical considerations. Journal of Oral Rehabilitation. 2011; 38(4):295-314. PMid:21133983. http://dx.doi.org/10.1111/j.13652842.2010.02148.x

25. Giraldez I, Ceballos L, Garrido MA and Rodriguez J. Early Hardness of Self-Adhesive Resin Cements Cured under Indirect Resin Composite Restorations. Journal of Esthetic and Restorative Dentistry. 2011; 23(2):116-124. PMid:21477039. http://dx.doi.org/10.1111/j.1708-8240.2011.00408.x

26. Giachetti L, Grandini S, Calamai P, Fantini G and Scaminaci Russo D. Translucent fiber post cementation using light- and dual-curing adhesive techniques and a self-adhesive material: push-out test. Journal of Dentistry. 2009; 37(8):638-42. PMid:19477571. http://dx.doi.org/10.1016/j.jdent.2009.04.007

27. Goracci C, Sadek FT, Fabianelli A, Tay FR and Ferrari M. Evaluation of the adhesion of fiber posts to intraradicular dentin. Operative Dentistry. 2005; 30(5):627-35. PMid:16268398.

28. De Munck J, Vargas M, Van Landuyt K, Hikita $\mathrm{K}$, Lambrechts $\mathrm{P}$ and Van Meerbeek B. Bonding of an auto-adhesive luting material to enamel and dentin. Dental Materials. 2004; 20(10):963-71. PMid:15501325. http://dx.doi. org/10.1016/j.dental.2004.03.002

29. Ilie $\mathrm{N}$ and Simon A. Effect of curing mode on the micro-mechanical properties of dual-cured self-adhesive resin cements. Clinical Oral Investigation. 2011. http://dx.doi. org/10.1007/s00784-011-0527-x

30. Khajotia SS. COMMENTARY. early hardness of selfadhesive resin cements cured under indirect resin composite restorations. Journal of Esthetic and Restorative Dentistry. 2011; 23(2):125. PMid:21477040. http://dx.doi. org/10.1111/j.1708-8240.2011.00409.x

31. Capa N, Aykor A, Ozel E, Calikkocaoglu S and Soyman M. Effect of Er:YAG laser irradiations on shear bond strength of three self-adhesive resin cements to dentin. Photomedicine and Laser Surgery. 2010; 28(6):809-21. PMid:20491574. http:// dx.doi.org/10.1089/pho.2009.2670

32. Bitter K, Noetzel J, Volk C, Neumann K and Kielbassa AM. Bond strength of fiber posts after the application of erbium:yttrium-aluminum-garnet laser treatment and gaseous ozone to the root canal. Journal of Endodontics. 2008; 34(3):306-9. PMid:18291282. http:// dx.doi.org/10.1016/j.joen.2007.12.011

33. Ramos RP, Chinelatti MA, Chimello DT, Borsatto MC, Pécora JD and Palma-Dibb RG. Bonding of self-etching and total-etch systems to Er:YAG laser-irradiated dentin. Tensile bond strength and scanning electron microscopy. Brazilian Dental Journal. 2004; 15(Special No):SI9-20. PMid:15690766. 